\title{
Coaching Program to Develop Teachers' Pedagogical Competence: A Description of Experience
}

\author{
Siti Tarwiyah ${ }^{1}$ \\ ${ }^{1}$ UIN Walisongo \\ 'sititarwiyah98@yahoo.co.id \\ NunaMustikawati Dewi ${ }^{2}$ \\ ${ }^{2}$ UIN Walisongo \\ 2nunamustikawati@yahoo.co.id \\ Lulut Widyaningrum ${ }^{3}$ \\ ${ }^{3}$ UIN Walisongo \\ ${ }^{3}$ lulutwidyaningrum@gmail.com
}

\begin{abstract}
The educational practices of Indonesian schools today are executed under the 2013 Curriculum. Although it has been implemented five years, problems of its realization are still found. It is partly due to insufficient knowledge and skills of teachers regarding planning, implementing, assessing and evaluating sequence learning processes. Coaching is one of the professional development programs which may enhance teachers' skill and will. It emphasizes good relationship between the coach and the coachee so that they can work as coworkers so that it makes the coachee feel at ease to consult the problems of learning. This paper shares some experiences of a coaching program to develop seven teachers' pedagogical competence of 5 Islamic Junior High Schools in Semarang. The implementation covers assessing needs, developing materials, designing assessment, presenting materials, implementing the materials, and making a reflection.
\end{abstract}

\section{ARTICLE HISTORY}

Received 22 September 2018

Accepted10 October 2018

\section{KEYWORDS}

Coaching; pedagogical competence; 2013 curriculum

\section{Introduction}

Coaching may equip the EFL teachers with pedagogical and content knowledge, which support effective EFL learning. Coaching exposes intensive enlightenment on the matters. The relationship between coach and coachees is made in such a way that enables them to work as coworkers who listen, care, and complete each other. Professional learning of this kind is needed due to the possibility to discuss the teachers' availability with the coach.

Analysis of ten research articles done by Vescio et al. (2006, pp. 6-8), supported the idea that professional learning leads to changes in teaching practice. Dunne et al. (2000) found that the classes of teachers who participated in critical friends groups became more student-centered over time. Englert and Tarrant (1995) studied changes in practice for three teachers within a learning community. Through 
participation in the learning community, one of the teachers implemented such changes in learning as implementing a new group story format and utilizing choral reading strategies. Hollins et al. (2004) proved teachers became more creative after attending the tenth meeting of professional learning. They designed a new approach to language arts instruction that involved letter writing, a poetry project, and class books, and employed the writing process. Strahan (2003) found the teachers participating in the efforts to improve student achievement in reading developed stronger instructional norms and made them receptive to working with a curriculum facilitator in the areas of changing practices for guided reading, writing, and selfselected reading.

This paper exposes the implementation of a short term coaching program and some experiences on the implementation. Seven teachers of private Islamic Junior High Schools in Semarang attended the program in the second semester of the 20182017 academic year.

\section{Coaching: an Overview}

Coaching is defined as "... the focused professional dialogue aims at aiding the coachees in developing specific professional skills to improve their teaching repertoire (Lofthouse, Leat\&Towler, 2010, p. 8). A coaching program encompasses four activities, i.e. (1) promoting professional dialogue on teaching issues that are of interest to the coachee, (2) planning, developing and evaluating teaching activities in collaborative way, (3) facilitating experimentation and reflection, and (4) fostering reflection that will help effective teachers when planning, and evaluating their teaching by discussing pedagogical issues in their teaching (McGrane\&Lofthouse, 2010, p. 188). Referring to the procedure, coaching gives access to the coachees to reach their pedagogical skill since they have a chance to plan, practice and making reflection after having professional dialogue.

Meanwhile, Elena Aguilar (2004) suggests,

"Coaching is an essential component of an effective professional development program. Coaching can build will, skill, knowledge, and capacity because it can go where no other professional development has gone before: into the intellect, behaviors, practices, beliefs, values, and feelings of an educator."

Furthermore, she reports the most thorough and comprehensive study on coaching which was done in 2004 by the Annenberg Foundation for Education Reform as follows: (1) Effective coaching encourages collaborative, and reflective practice, (2) Effective embedded professional learning promotes positive cultural change, i.e., School-based culture and conditions, (3) Coaching was also linked to teachers' increase in using data to inform practice, (4) Coaching promotes the 
implementation of learning and reciprocal accountability between a coach and the client, (5) Coaching supports collective leadership across a school system since it uses the relationships between coaches, principals, and teachers to create the conversation. This conversation leads to behavioral, pedagogical, and content knowledge change.

Regarding the benefits of coaching as having been mentioned above, every school unit needs to prioritize funding for conducting coaching to enhance its teacher professionalism. It is also essential for the school to make sure that the coaching runs efficiently by making a good plan, controlling the process, and following up it with class supervision or mentoring.

In order to realize its goals, the coach and the coachees need to agree on what they will do in the program. The activities must be in line with and for the sake of pursuing the coachees' goals/needs and solving their problems. Inc (2005, p. 21) reminds three features of coaching, i.e. (1) synergy, good relationship between coach and coachees to accomplish the coachees' needs and goals, (2) structure, with a coach, a coachee takes more action, thinks bigger, and gets the job done, (3) expertise, the coach knows how to help coachees do their job more efficiently, make better decisions, set the best goals, and restructure their professional and personal lives for maximum productivity. A preliminary meeting between the two parties is important to know the coachee's goals, needs, and problems, to build synergy, and to set a plan to reach the goals.

\section{The Implementation of the Coaching Program}

The coaching program was carried out in six weeks. It encompassed assessing needs, developing materials, designing assessment, presenting materials, implementing materials, and reflection. The following part explains the activities and the content of each component.

\section{Assessing Needs}

Need assessment was done through observing the teaching and learning process of the teachers before the coaching program was carried out and through Focus Group Discussion. The data were got from observing the teaching and learning processes before the coaching program was started as well as from reviewing lesson plans uncovered the following information:

- The teachers' understanding of the implementation of the 2013 Curriculum was limited.

- The teachers had problems with designing activity-based learning. Consequently, they still played a role more as information sources than 
facilitators. Playing that role was considered more practical while, designing activity-based learning was more time-consuming.

- The teachers had problems in planning and conducting assessment; composing lattice of the instrument, instrument, and scoring rubric. Some instruments were linguistically and conceptually incorrect, with inappropriate instruction.

In the Focus Group Discussion, the materials planned to be presented was also informed. The teachers proposed the exposure to some language teaching strategies which support the realization of activity-based learning.

\section{Developing Materials}

The materials were developed based on the process and the assessment standards covered in Permendikbud No. 22 and 23 the Year 2016 and by considering the teachers' needs. The table below shows the materials presented and discussed:

Table 1 List of Coaching Materials

\begin{tabular}{|c|c|c|}
\hline No. & Coaching Materials & Description \\
\hline 1 & Teacher Competencies & $\begin{array}{l}\text { Breaking down the indicators of the four } \\
\text { teacher competencies in order to be aware of } \\
\text { the competencies which need to be possessed }\end{array}$ \\
\hline 2 & $\begin{array}{l}\text { Competence Standards of } \\
\text { English for Junior High } \\
\text { School }\end{array}$ & $\begin{array}{l}\text { Understanding the Core Competence, Basic } \\
\text { Competence, and related teaching materials }\end{array}$ \\
\hline 3 & $\begin{array}{l}\text { Implementing contextual } \\
\text { language learning }\end{array}$ & $\begin{array}{l}\text { The features of contextual teaching } \\
\text { - There is teamwork among students in the } \\
\text { class. } \\
\text { - Emphasizing on problem-solving } \\
\text { - Accommodating students' backgrounds } \\
\text { - Fun, not a boring teaching } \\
\text { - Integrated learning (theory, practice, skills) } \\
\text { - Making use of various sources } \\
\text { - Students' engagement } \\
\text { - Students' sharing } \\
\text { - Critical students and creative teacher } \\
\text { - Products of learning; pictures, articles, } \\
\text { humor, etc. }\end{array}$ \\
\hline 4 & $\begin{array}{l}\text { Formulating questions to } \\
\text { stimulate student } \\
\text { Order Thigh } \\
\text { (HOTS) }\end{array}$ & $\begin{array}{l}\text { Preparing questions in the six levels; knowing, } \\
\text { understanding, applying, analyzing, } \\
\text { evaluating, creating }\end{array}$ \\
\hline 5 & $\begin{array}{l}\text { Teaching the four } \\
\text { language skills }\end{array}$ & $\begin{array}{l}\text { Implementing varied activities to facilitate } \\
\text { student integrated language learning }\end{array}$ \\
\hline
\end{tabular}




\begin{tabular}{|c|c|c|}
\hline 6 & Planning a lesson & $\begin{array}{l}\text { The competence in planning the teaching- } \\
\text { learning process covers } \\
\text { - describing objectives } \\
\text { - selecting materials } \\
\text { - determining methods and strategies } \\
\text { - determining learning sources, media } \\
\text { - designing assessment and evaluation } \\
\text { instruments } \\
\text { - determining assessment and evaluation } \\
\text { techniques } \\
\text { - allocating time }\end{array}$ \\
\hline 7 & Implementing a lesson & $\begin{array}{l}\text { Teaching learning process competence is } \\
\text { reflected in the competences in } \\
\text { - opening lesson } \\
\text { - delivering materials } \\
\text { - using media and methods } \\
\text { - using communicative language } \\
\text { - motivating students } \\
\text { - organizing activities } \\
\text { - interacting with students communicatively } \\
\text { - concluding lessons } \\
\text { - providing feedback } \\
\text { - conducting assessment and evaluation } \\
\text { - Using time effectively. }\end{array}$ \\
\hline 8 & $\begin{array}{l}\text { Assessing and evaluating } \\
\text { a lesson }\end{array}$ & $\begin{array}{l}\text { The competence of assessment and evaluation } \\
\text { covers } \\
\text { - choosing questions based on the level of } \\
\text { difficulty and discriminating power } \\
\text { - checking the answers } \\
\text { - repairing problems } \\
\text { - classifying and processing the results } \\
\text { - interpreting, determining the correlated } \\
\text { problems } \\
\text { - arranging follow-up programs } \\
\text { - identifying the needs for follow-up, } \\
\text { carrying out the follow-up, analyzing the } \\
\text { results of the evaluation }\end{array}$ \\
\hline
\end{tabular}


The assessment instrument used to assess the teachers' pedagogical competence had been prepared and used in the first observation to get the data of the teachers' pedagogical competence before being coached in EFL learning. Designing assessment in this part refers to designing the worksheet used during the coaching program. Some samples of worksheets are provided in the explanation of presenting materials.

\section{Presenting Materials}

The coaching carried out in this research was aimed at strengthening the teachers' pedagogical competence in the context of the 2013 Curriculum. Meanwhile, the main feature of learning of the curriculum is activity-based learning, which is represented through such characteristics as being interactive and inspiring, being enjoyable, challenging, motivating active participation of students, being contextual and cooperative, giving enough space to idea, creativity, and self-reliance, being based on talent, interest, ability, physical and psychological development of students. To model the implementation of activity-based learning, the coaching program implemented coachee-centered coaching. It was a coaching program which prioritized the active participation of the coachees.

To implement coachee-centered coaching, some teaching methods suggested in the 2013 Curriculum were used to present the materials. Some of them were Scientific Approach, Problem-Based Learning, Task-Based Learning, Inquiry Learning, and Presentation- Practice-Production. Coachee-centered coaching program was expected to stimulate the coachees' awareness of the teaching methods, and they were spirited to implement them.

The material presentation spent 16 hours. Researcher as the resource person tried to implement participant-centered sessions. It was represented by choice of method in every session. Before starting the session, the researcher usually shared or invited the teachers to share some teaching strategies, warmer, or filler in the form of a game or song. Each material was supported with individual or pair worksheet.

As the materials were packed based on need analysis of the teachers, they joined almost every session enthusiastically. Some questions were raised. The teachers' understanding of the materials still needed to be improved. This was proven from the way they did their worksheet which was still imperfect. Some questions were not answered, and some answers were not written comprehensively. That might be due to much school work they had to handle, which spent most of their time at the school. It might also be due to their insensitivity to analyze the problems.

The following part provides the example of the worksheets and the participants' response.

a) Example 1 


\section{Coaching Worksheet I}

Recall the following learning principles and the components of activity-based learning then make a reflection on your previous teachings to identify whether they met the principles and the components!

\section{LEARNING PRINCIPLES}

\section{(PERMENDIKBUD 65/2013 \&PERMENDIKBUD 22/2016)}

1. from being informed to learning, through learning activities, learners are stimulated to search for rather than given information;

2. from the teacher as the only source of learning to varied sources of learning;

3. from textual to process approach which emphasizes on scientific approach;

4. from content-based learning to competency-based learning;

5. from partial to integrated learning;

6. from learning which ends up with the sole answer to multi-dimensioned answers;

7. from verbal learning to learning which facilitates applied skills;

8. the improvement of balance between physical dan mental skills (hard and soft skills);

9. learning which prioritizes culturalization and empowerment of learners as long-life learners;

Ten learning which implements modeling values (ingngarso sung tulodho), boosts students' ideas and willingness (ingmadyamangunkarsa), and grows students' creativity (tut wurihandayani);

11 learning which is not only conducted at school but also home and students' community;

12 learning which implements the principle that anyone is a teacher, anyone is a student, and anywhere is class.

13 learning which makes use of information and communication technology to enhance the efficiency and the effectiveness of learning;

14 learning which acknowledges individual cultural background differences of learners.

\section{AN ACTIVITY-BASED LEARNING}

1. being interactive and inspiring;

2. being enjoyable, challenging, motivating active participation of students;

3. being contextual and cooperative;

4. giving enough space to the idea, creativity, and self-reliance;

5. is based on talent, interest, ability, physical and psychological development of students.

Figure 1 Coaching Worksheet 1: Teaching Principles and Activity-Based Learning

The above worksheet exposes the participants with 14 principles of the teaching of the 2013 Curriculum and the characteristics of activity-based learning. 
Through completing the worksheet, it was expected that the participants would be aware of implementing all the principles and the features completely to reach effective and efficient teaching. The idea may be taken from the principles is that teaching does not only equip students with textual knowledge but also contextual knowledge, not only hard skill but also a soft skill.

Nevertheless, the participants seemed unaware of the purpose of exposing them to the principles. The following simple response proved it:

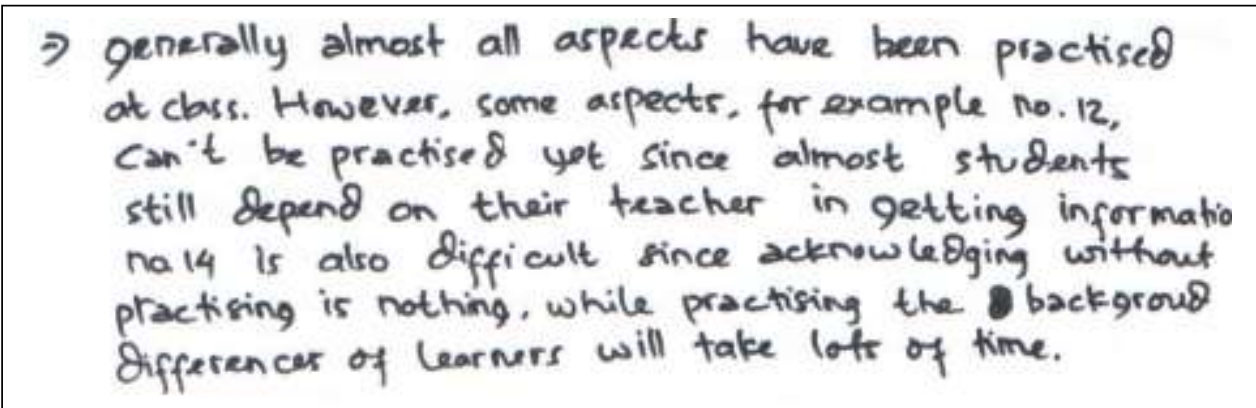

Figure 2 Sample of participant's work 1

The participants were not sensitive in assessing and responding the principles and the characteristics one by one and coming up with such a simple response. Regarding the fact, the coach reviewed the principles and the characteristics one by one supported with examples. The coach also implemented a dynamic assessment. It is a formative assessment which provides a chance for students to learn while being assessed.

... some learning has to take place within the assessment. This means that the learners should receive feedback from the mediator during assessment: responses to the questions tested and clues to where errors were made. (Teo\& Jen, 2012, p. 10)

b) Example 2 


\section{Coaching Worksheet 3}

\section{The features of contextual learning}

- There is teamwork among students in the class.

- Emphasizing on problem-solving

- Accommodating students' backgrounds

- Fun, not a boring teaching

- Integrated learning (theory, practice, skills)

- Making use of various sources

- Students' engagement

- Students' sharing

- Critical students and creative teacher

- Products of learning; pictures, articles, humor, etc.

Questions:

1. Find the activities in the video showing each feature of contextual learning!

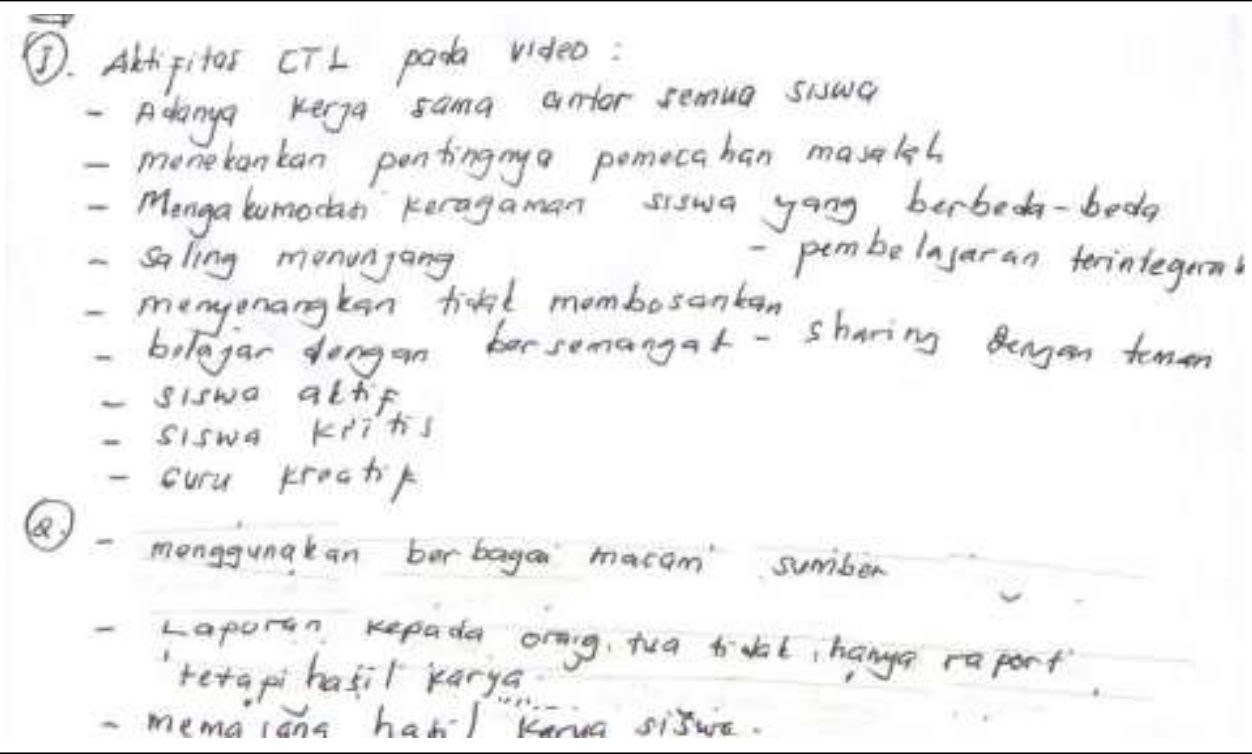

Figure 4 Sample of Participant's Work 2

Participant's work two also shows an incorrect answer to the questions. The participant did not answer based on the questions. The answers represent the low degree of critical thinking. The answers to question number 2 indicate that the teacher was not accustomed to making teaching reflection. 
Warmer was always given at the beginning of the coaching sessions. One of the warmers was 'explain yourself.' The participants gathered in a small circle and read a statement on their card blaming or accusing the other participant. The blamed participant had to explain his defense that the accusation is wrong. Below are the examples of the accusation.

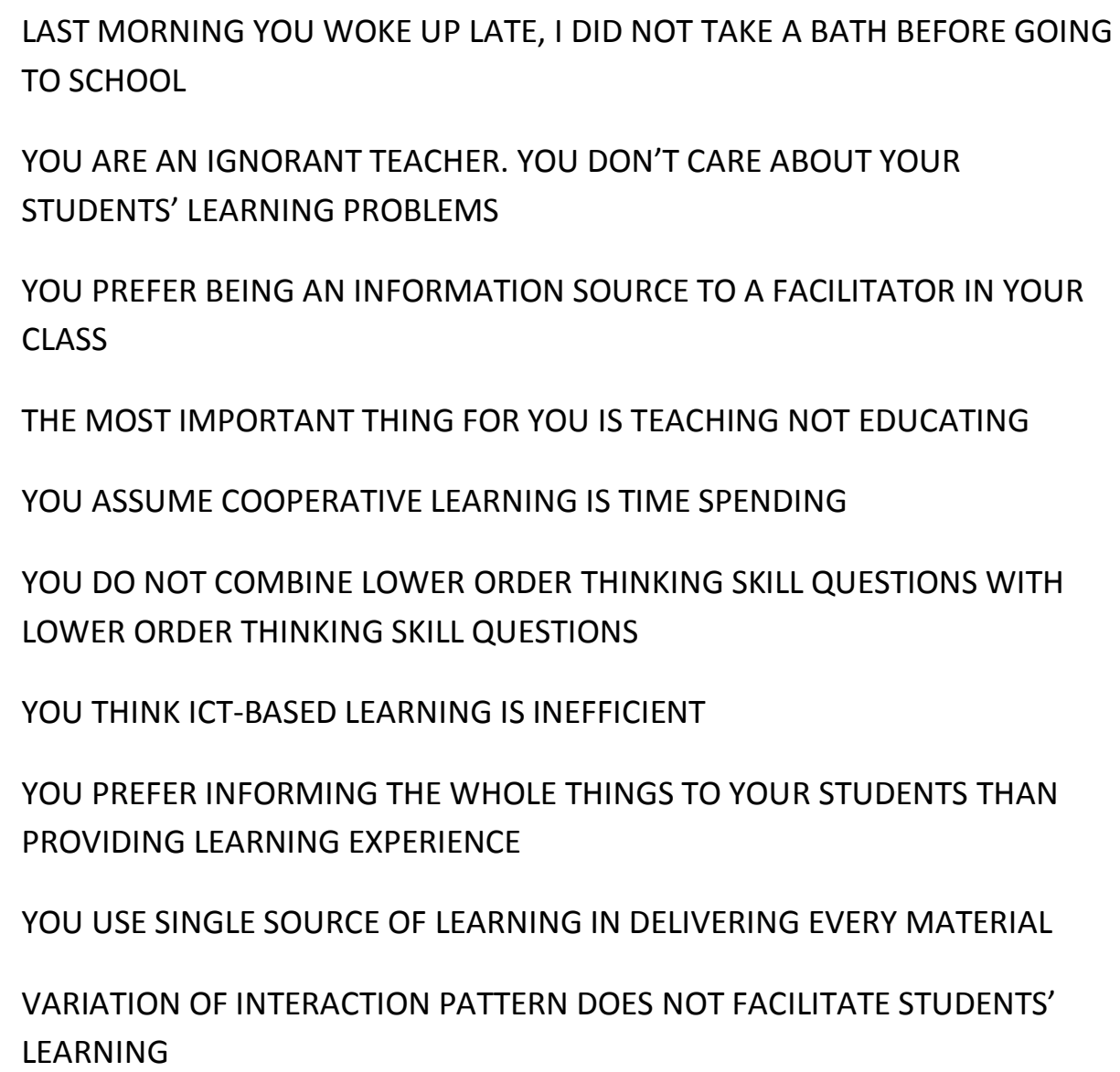

The warmer was intentionally designed to expose the teachers to some features of learning and assessment of the 2013 Curriculum. Other examples are 'If I am ... I will ...' and 'from word to sentence.' In 'If I am ...' each participant made a sentence in turn by using the if clause as the main clause. The first statement was made by the coach leading to statements of professional development. For example, If I become a professional teacher, I will teach my students efficiently $\rightarrow$ If I teach my students efficiently, I will reach the learning aims, etc.

'From word to the sentence' is vocabulary and sentence practice for elementary level. With time allocation 8-10 minutes, the activity is aimed at enriching students' vocabulary and strengthening the students' understanding of sentence construction. It is implemented based on the following procedure:

- The class is divided into two big groups 
- Teacher gives the word to group A and group A must find a word beginning with the last letter of the given word.

- Group B does the same thing; find a word beginning with the last letter of group A's word, and so on.

Below is an example of the chained words.

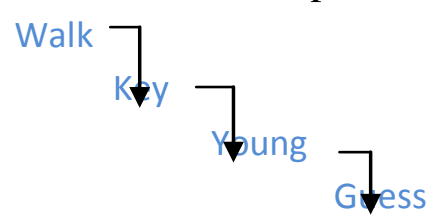

- After the teacher considers that vocabulary break down is enough, then s/he assigns students to use each word to construct a sentence in turn, just like the previous activity.

Below is an example of sentence construction.

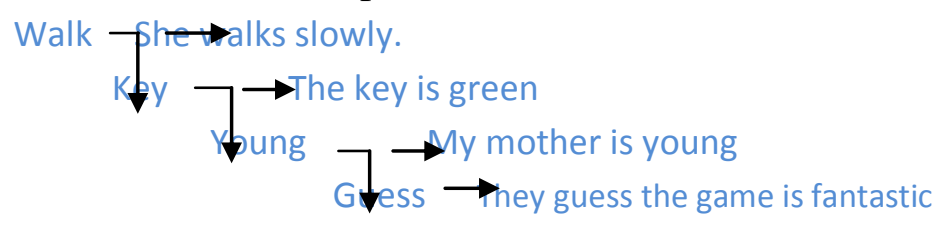

- The group with the right words and sentences is the winner.

\section{Implementing Materials}

Implementing the materials which have been exposed, and the skills which have been demonstrated in a coaching program is essential to enhance teachers' teaching skill. It becomes one of the critical concepts of coaching. A coaching program must give: (1) repeated opportunities to practice the demonstrated skill in both simulated and actual classrooms, (2) repeated feedbacks on the practice efforts (Keith \& Robert, 1991, pp. 200-204).

Ideally, the teaching practice is planned, developed, and evaluated collaboratively (McGrane \& Lofthouse, 2010, p. 188). It is due to giving space to the coachees to peer-learn. Due to the difficulties in time management, preparation was done individually.

Three roles are ideally played in teaching practice. The roles are resource provider, facilitator, and counselor. Resource providers expose students to conceptually and contextually correct graded materials. Facilitators create a good learning environment, boost students' initiative and motivation, implement studentcentered learning to develop language competence and performance, take individual learner difference into account, select materials, organize language practice, and facilitate students to make conclusion and reflection, inform what to learn and/or gave assignment for the coming learning in the closing stage. Counselors help students dealing with emotion, mood, interest, motivation, attitude, and anxiety which are influential on their learning behavior and outcome (Arnold, 2000, cited in 
Han, 2017, p. 135). Those three roles are primary in developing learner autonomy (Voller, 1991, cited in Han, 2017, p. 135).

The implementation session was done through individual real teaching. Every participant taught a class based on the lesson plan s/he had prepared. The teachers needed to pay attention to the completeness of the components of the lesson plan. Previously, they were not accustomed to putting materials and learning activity for remedial and enrichment learning in their lesson plan. However, it was obligatory to cover based on the revised edition of the 2013 Curriculum.

The researcher monitored the teaching. During monitoring the teaching, three competencies were assessed, their problems and progress were noted. Planning competence was identified through the lesson plan. Implementing competence, together with assessing and evaluating competence was exposed through teaching practice.

It might be noted that the teachers made some progress concerning planning, implementing, assessing and evaluating. The progress was varied from one teacher to another teacher. Their lesson plans had more complete components. They completed with materials and activities for remedial and enrichment learning, scoring rubric, and more related worksheet to indicators. Some of them did not forget to explain learning goals, main stages of learning, coverage of the materials, the scope of assessment, and getting information about the level of students' comprehension of the lesson in the opening stage. They played a variety of roles and implemented varied kinds of learner-centered activities and interaction patterns in the main stage. The roles which are ideally played are resource provider, facilitator, and counselor.

One problem still often met was the skill to instruct questioning stage. Questioning in this stage is aimed at stimulating students' critical thinking skill, which is a part of the 21st-century skills which must be taught to students. Nevertheless, the questions are from teachers instead of from students. What was met in most of the observed classes was the teacher's question to students. Eliciting questions from students is hard. Especially if the students are not familiarized with questioning. Questioning stimulates students to be critical.

It was also noted that teachers seemed to be afraid of going beyond the scientific approach. They still used it as the main approach. The revised version of the 2013 Curriculum suggests teachers use any approach and strategy as far as it leads to activity-based learning.

Two teachers' teachings activities were identified as less dynamic. Their pace was still slow; their teaching activities were less varied than the other four teachers'. These two teachers were relatively new in that school. Through the coaching program, much pedagogical knowledge was learned either from the source person or from the co-teachers. 


\section{Making Reflection and Evaluation}

Reflection is an inseparable part of a coaching program. Reflection makes teachers aware of their strengths and weaknesses in teaching. It sensitizes teachers with policies for the next teaching. "... reflection ... will help effective teachers when planning and evaluating their teaching by discussing pedagogical issues in their teaching" (McGrane \& Lofthouse, 2010, p. 188).

When writing a reflection, the teachers forget to describe their teachinglearning process briefly. Ideally, a teaching reflection comprises introduction: giving a brief description about the teaching-learning process, analysis: identifying the strengths and the weaknesses of the teaching, evaluation: formulating a plan for the future learning when teaching the same or different materials.

After teaching was done, every teacher made a reflection. Since some teachers had to continue teaching to their classes directly after the observed teaching, the reflection was made in written form. It was aimed at giving enough time for teachers to write reflection as comprehensive as possible. The written reflection was given to a researcher in order to get feedback. Below is an example of teacher reflection.

Hari ini saya melanjutkan materi Deskriptive Text yang terdapat pada KD 3.7.Pembelajaran saya awali dengan menyebut nama-nama benda yang ada di dalam kelas kemudian saya membagi siswa menjadi beberapa kelompok untuk menyusun kalimat acak menjadi sebuah paragraph. Siswa tampak senang dan menikmati kegiatan diskusi kelompok. Selanjutnya perwakilan kelompok menyampaikan hasil diskusi di depan kelas. Sebagian siswa masih merasa bingung dalam menyusun kalimat acak menjadi paragraph. Solusi awal yang akan saya terapkan pada pembelajaran berikutnya adalah dengan membahas bersama-sama garis besar isiteks tersebut sebelum memberitugas yang sama

Figure 6 Sample of Teacher Reflection

The reflection above has been clear, but the teacher still needs to make the reflection more comprehensive by giving more details about the exposed materials, a method of exposure and media, assessment, and students' response. Boody (2008, cited inRerung, 2013, p. 293) mentions four levels of teacher reflection: (1) teacher reflection as retrospective analysis (ability to self-access), (2) teacher reflection as a problem solving process (awareness of how one learns), (3) critical reflection of self (developing continuous self-improvement), and (4) reflection on beliefs about the self, how they prepare their lesson plan, delivering them, and eventually evaluate them are basically and strongly influenced by their belief towards themselves and others. The reflection above may be classified into the second level. The teacher focused more on the students' learning, not on his teaching. Detailed reflection is the 
Siti Tarwiyah ,Nuna Mustikawati Dewi, Lulut Widyaningrum | 120

way how a teacher learns from his teaching experience in order to experience better teachings.

A reflection meeting was conducted after all teachers did observe teaching. In that meeting, every teacher shared their reflection. Other teachers commented and gave feedback. The purpose of conducting the reflection meeting was to learn from other experiences. 


\section{References}

Aguilar, E. (2004). The Art of Coaching: Effective Strategies for School Transformation.Retrieved November 6, 2014, fromhttp://www.edutopia.org/blog/coaching-impact-teachers-principalsstudents-elena-aguilar.

Inc, Coach U. (2005). Essential Coaching Practice: Your Complete Practice Resource. New Jersey: John Wiley and Sons Inc.

KementerianPendidikandanKebudayaan.(2016). Permendikbud No. 22/2016 on Process Standard. Jakarta.

KementerianPendidikandanKebudayaan.(2016). Permendikbud No. 23/2016 on Assessment Standard. 2016. Jakarta.

Lofthouse, R., Leat, D. \&Towler, C. (2010).Coaching for teaching and learning: a practical guide for schools. Guidance Report. National College for Leadership of Schools and Children's Services: CfBT Education Trust. Retrieved August 25 , 2016, from https://www.gov.uk/government/uploads/system/uploads/attachment_data/file/ 327944/coaching-for-teaching-and-learning.pdf

McGrane, J. \&Lofthouse, R. (2010).Developing Outstanding Teaching and Learning: Creating a Culture of Professional Development to Improve Outcomes. London: Optimus Education.

Rerung, T.M.K. 2013. Exploring the Critical Reflective Teaching: from Classroom Practice into Self-Evaluation. Proceeding from 2nd English Language Teaching, Literature and Translation International Conference (pp. 291-299). Semarang: English Department of UNNES.

Vescio, Vicki, et al. 2006. "A review of research on professional learning communities: What do we know?" Presented at the NSRF Research Forum, January 2006. 